\title{
Growth and Seed Quality of Sunflower (Helianthus Annuus L.) Cultivars as Affected by Nitrogen Fertilizer and Defoliation Rates
}

\author{
Abdullah Ahmed Bjaili, Samir G. Al-Solaimani and Fathy S. EL-Nakhlawy \\ Department of Arid Land Agriculture, \\ Faculty of Meteorology, \\ Environment \& Arid Land Agriculture, \\ King Abdulaziz University
}

\begin{abstract}
This work was conducted in 2017 and 2018 cropping seasons at the Agricultural Research Station of King Abdulaziz University at Hada Al-Sham, to study the responses of 3 sunflower cultivars (Egyptian cv. Sakha -53, Argentina cv. Argentina -11 and Turkish cv. May Hybrid ) to nitrogen fertilizer rates $(100,200$ and $300 \mathrm{~kg} \mathrm{~N} / \mathrm{ha})$ and defoliation levels $(0,2$ and 4 leaves/plant). The results showed significant effects of $N$, defoliation and cultivars and their interactions on all studied parameters. Application of nitrogen fertilizer at $300 \mathrm{~kg}$ $\mathrm{N} / \mathrm{ha}$ increased days to flowering, seed protein content and total chlorophyll contents, while seed oil content was reduced. Removal of 4 leaves (defoliation) of the sunflower cultivars significantly increased plant heights, percentages of seed oil, seed protein, and leaf chlorophyll content. The Egyptian variety 'Sakha 53' produced the highest percentage of seed oil followed by 'May Hybrid' and 'Argentina-11'. The Turkish 'May Hybrid' showed the highest protein content followed by 'Sakha 53' and 'Argentina-11'. Removing 4 leaves of "'Sakha 53' revealed the highest oil content, while the 'May Hybrid' under 2 leaves removal produced the highest protein content. The Egyptian cultivar 'Sakha 53' suggested to cultivate under arid land climate with high rate of Nitrogen fertilizer and defoliation 2-4 leaves from plant bottom at flowering stage.
\end{abstract}

Key words: Nitrogen fertilizer, defoliation rate, sunflower, seeds quality, yield components

\section{I.INTRODUCTION}

Sunflower plants efficiency for exploitation of nitrogen is relatively high, and the addition of nitrogen increases the height of the plant (Frazen, 2016). There was significant increase in the length of the sunflower plant, the dry weight of the plant, with increase in the nitrogen fertilization rate from zero to $184 \mathrm{~kg} \mathrm{~N} / \mathrm{ha}$ (Salih, 2013). The total biomass production was significantly increased in the tested sunflower cultivars under three levels of nitrogen fertilizer (Mina Kiani et al., 2016). There was more biomass production in sunflower hybrids due to $\mathrm{N}$ fertilization, and $\mathrm{N}$ was absorbed at high rate during biomass production (Laura, 2015). N fertilization significantly increased plant height, root length, leaf area, fresh biomass, straw yield in sunflower (Aripa et al. 2016). Under use of three rates of 0, 100, and $200 \mathrm{~kg}$ nitrogen per hectare on two safflower cultivars, there was increase in biomass production (leaves, stems), and in dry matter (Dordas, and Sioulas, 2009). N is often the most restrictive factor in crop production (Jurg et al., (2008). Many researchers worked on this field of effects of leaves removal on agronomic characters of sunflower, and the treatment of 3 sunflower cultivars with three levels of leaf removal (without removing leaves, removing 4 leaves and removing 8 leaves) resulted in highest values for plant height, stem diameter, leaf area, for the treatment without removing of leaves (AL-Dori and Hassan, 2011). After removal of leaves from castor oil plant (Ricinus communis) at rate of $0,15,30,45$ or $60 \%$ of the total leaf area to assess the effect of leaf fall on growth and production components, the total area of leaves were reduced but plants were able to fully regrow the leaf area (Severinoa et al. 2010). The removal of 50\% of the sunflower leaf area in different plant growth stages, indicated that removal of leaves during vegetative stage initiated significant increase in the leaf area (Moriondoa et al. 2003). The process of leaf removal from three varieties of Sunflowers cultivars Morden, Flame and Manon, with three levels (without removing leaves, removing 4 leaves and removing 8 leaves), resulted in significant differences between varieties in plant height, stem diameter, leaf area, and seed oil and protein percentages (AL-Dori and Hassan 2011). There were significant differences between the varieties of the sunflower plant in response to the removal of leaves (defoliation) (Presottoa et al. 2017). When three sunflower cultivars were subjected to three levels of leaf removal (without removing leaves, removing 4 leaves and removing 8 leaves) the highest values for seed oil percentage was for the treatment without removing of leaves, and the treatment with the removal of 8 leaves gave the highest protein content in the seeds (AL-Dori and Hassan, 2011). Under test of defoliation effect at four levels $(0-4-8-12$ leaves) from the stem base of the sunflower plants before the start of flowering, significant effect of leaves removal occurred on many sunflower traits, including reduction of the total seed production of oil and protein content (Karadogan et al. 2009). Removal of leaves from castor oil plants caused reduction in seed oil content (Severinoa et al. 2010). This research study aimed to test the growth, yield components and seed quality of 3 sunflower cultivars (Egyptian cv. Sakha -53, Argentina cv. Argentina 11 and Turkish cv. May Hybrid ) to nitrogen fertilizer rates $(100,200$ and $300 \mathrm{~kg} \mathrm{~N} / \mathrm{ha})$ and defoliation levels ( 0 , 2 and 4 leaves/plant). 


\section{MATERIALS AND METHODS:}

\section{Experimental Design}

This study was carried out in the Agricultural Research Station at Hada Al Sham, King Abdul Aziz University in 2017 and 2018 cropping seasons, to study the effects of N, defoliation and cultivar treatments on the sunflower crop growth and its components and seed quality. The experiments were laid out in in split- split plot design using four replicates. The nitrogen fertilizers rates $(\mathrm{N} 1: 100 \mathrm{~kg}$ $\mathrm{N} / \mathrm{ha}, \mathrm{N} 2: 200 \mathrm{~kg} \mathrm{~N} / \mathrm{ha}$ and N3: $300 \mathrm{~kg} \mathrm{~N} / \mathrm{ha}$ ) were distributed over the.main plots, The defoliation rates (: F1: without leaf removal F2: Removal of 2 leaves F3: Removal of 4 leaves.) were distributed over the sub-plots and the sunflower cultivars (Cv1: Egyptian cultivar : Sakha - 53, Cv2: Argentina cultivar: Argentina-11, Cv3: Turkish cultivar : May hybrid) were distributed over the sub- sub plots. The plots sizes were $3.20 \mathrm{~m} \times 2.1 \mathrm{~m}$ and contained 8 rows with distance $40 \mathrm{~cm}$ and $30 \mathrm{~cm}$ between plants. Plots were fertilized before planting with mono superphosphate (P2O) at $100 \mathrm{~kg} / \mathrm{ha}$, potassium (K2O) at $100 \mathrm{~kg} / \mathrm{ha}$. The nitrogen rates were applied at equal dosages after 15, 30, 45 and 60 days from planting.

\section{Analysis of soil before planting:}

Before planting, the soil properties were determine including: soil organic matter, soil $(\mathrm{pH})$, soil $(\mathrm{EC})$, soil content of the major elements (nitrogen, phosphorus and potassium), according to Pansue and Gautherlou (2006) (Table 1).

TABLE (1) INITIAL SOIL ANALYSIS OF THE EXPERIMENTAL SITE BEFORE PLANTING

\begin{tabular}{|c|c|c|c|c|c|c|}
\hline \multirow{2}{*}{ Soil Depth } & \multirow{2}{*}{$\mathbf{p H}$} & $\mathbf{E C}$ & $\mathbf{O M}$ & \multicolumn{2}{|c|}{ (N) } & \multicolumn{2}{|c|}{ (P) } & (K) \\
\cline { 3 - 7 } & & $\mathbf{d S} \mathbf{~ m - 1}$ & $\mathbf{( \% )}$ & \multicolumn{3}{|c|}{)} \\
\hline $0-15 \mathrm{~cm}$ & 7.27 & 3.26 & 0.651 & 500 & 42.10 & 570 \\
\hline $15-30 \mathrm{~cm}$ & 7.38 & 2.5 & 0.990 & 700 & 35.30 & 460 \\
\hline
\end{tabular}

\section{Measurements}

Growth parameters

Six random plants were chosen within each experimental plot and the following parameters were measured: date to flowering (50\% flowering plants), Plant height at harvesting $(\mathrm{cm})$ and Leaf area index $(\mathrm{cm})$.

Seed quality parameters

Seed oil content (\%) according to A.O.A.C (2000) using Soxtech with Hexane organic solvent at $\left(60^{\circ} \mathrm{C}\right)$. , Seed protein content (\%) using Kjeldahl instrument according to (AOAC 2000).

Soil characteristics after harvest:

After harvest, the soil was analyzed for Soil content of nitrogen $(\mathrm{N})$, Soil salinity (Ec), Soil salinity $(\mathrm{Ec}), \mathrm{pH}$ number of soil $(\mathrm{pH})$.

Data Analysis:

Statistical analysis were done for the results recorded in each season according to the type of statistical design used in the study, and after applying the assumptions and of the statistical analysis by analysis of variance of each of the measured data of the studied traits. The statistical comparisons of the treatments means will be test by RLSD at $\mathrm{P}<0.05$, according to El- Nakhlawy (2010) and using SAS (SAS, 2006).

\section{RESULTS}

\section{Growth parameters}

The results showed that there was a significant effect of nitrogen fertilization rates on flowering dates and plant height, while there was no effect on the leaf area index (LAI), and defoliation significantly affected plant height, while the effect of the cultivars was on the three traits (flowering date, plant height and LAI). There was a significant effect of the interaction between fertilization and defoliation rates on plant growth in in the two seasons (2016-2017 / 2017-2018), Table (2).

TABLE (2) ANALYSIS OF VARIANCE OF FLOWERING DATE, PLANT HEIGHT AND LEAF AREA INDEX (LAI) OF SUNFLOWER UNDER THE EFFECTS OF NITROGEN FERTILIZER RATES, DEFOLIATION, CULTIVARS AND THEIR INTERACTIONS DURING $2016 / 2017$ AND $2017 / 2018$ SEASONS

\begin{tabular}{|c|c|c|c|c|c|c|c|c|}
\hline \multirow{2}{*}{ Source of variation } & \multirow{2}{*}{ df } & \multicolumn{2}{|c|}{ Flowering date } & \multicolumn{3}{|c|}{ Plant height (cm) } & \multicolumn{2}{|c|}{ LAI (m2/m2) } \\
\hline & & $2016 / 17$ & $2017 / 18$ & $2016 / 1$ & & $17 / 18$ & $2016 / 17$ & $2017 / 18$ \\
\hline Replicates & 3 & $2.53 \mathrm{NS}$ & $0.40 \mathrm{NS}$ & $16.98 \mathrm{I}$ & & 05NS & $1.78 \mathrm{NS}$ & $1.96 \mathrm{NS}$ \\
\hline \multicolumn{2}{|c|}{ Nitrogen fertilizer rates (N) } & 2 & $12.39 * *$ & $0.68 \mathrm{NS}$ & $1715.45 * *$ & $1129.56 * *$ & $2.15 \mathrm{NS}$ & $0.36 \mathrm{NS}$ \\
\hline \multicolumn{2}{|l|}{ Error (a) } & 6 & 1.11 & 0.404 & 25.38 & 10.18 & 1.28 & 1.14 \\
\hline \multicolumn{2}{|l|}{ Defoliation (D) } & 2 & $0.23 \mathrm{NS}$ & $2.06 \mathrm{NS}$ & $160.02 * *$ & $305.00 * *$ & $1.07 \mathrm{NS}$ & $1.12 \mathrm{NS}$ \\
\hline \multicolumn{2}{|l|}{$\mathbf{N * D}$} & 4 & $0.84 \mathrm{NS}$ & $1.38 \mathrm{NS}$ & $8.64 \mathrm{NS}$ & $8.04 \mathrm{NS}$ & $0.18 \mathrm{NS}$ & $0.15 \mathrm{NS}$ \\
\hline \multicolumn{2}{|l|}{ Error (b) } & 18 & 0.83 & 1.12 & 8.75 & 8.36 & 0.36 & 0.54 \\
\hline \multicolumn{2}{|l|}{ Cultivars (V) } & 2 & $403.73 * *$ & $11.342 \quad * *$ & 20017.55 & $4181.31 * *$ & $1.34 *$ & $1.98 *$ \\
\hline \multicolumn{2}{|l|}{$\mathbf{N} * \mathbf{V}$} & 4 & $0.84 \mathrm{NS}$ & $0.08 \mathrm{NS}$ & $32.14 * *$ & $26.70 *$ & $0.34 \mathrm{NS}$ & $0.99 \mathrm{NS}$ \\
\hline \multicolumn{2}{|l|}{ D*V } & 4 & $1.46 \mathrm{NS}$ & $1.342 \mathrm{NS}$ & $15.79 *$ & $20.27 *$ & $0.32 \mathrm{NS}$ & $0.56 \mathrm{NS}$ \\
\hline \multicolumn{2}{|l|}{$\mathbf{N} * \mathbf{D} * \mathbf{V}$} & 8 & $1.80 \mathrm{NS}$ & $0.22 \mathrm{NS}$ & $7.19 \mathrm{NS}$ & $2.92 \mathrm{NS}$ & $0.68 \mathrm{NS}$ & $0.97 \mathrm{NS}$ \\
\hline \multicolumn{2}{|l|}{ Error (c) } & 54 & 1.07 & 1.34 & 5.84 & 7.43 & 0.38 & 0.52 \\
\hline
\end{tabular}

NS: Not significant at $\mathrm{P} \leq 0.05 *$ : significant at $\mathrm{P} \leq 0.05 * *$ : significant at $\mathrm{P} \leq 0.01$ 
Effects of nitrogen rates on Sunflower agronomic traits Flowering date:

Mean comparison results of the effect of the dates of flowering, plant height, and leaf area index (LAI) in table (3) showed that there are significant differences between the date of flowering under the influence of the three nitrogen fertilization rates, with the highest flowering date (64.36 days) being under $300 \mathrm{kgN} / \mathrm{ha}$ during the first season, and no significant differences during second season. And flowering date during the first season ranged between 64.36 days to 63.30 days), while in the second season it ranged between (57.47 days to 57.22 days).
Plant height:

The results (table 3) indicate significant increase in plant height with increase in $\mathrm{N}$ rates from 100 to $300 \mathrm{~kg} \mathrm{~N} / \mathrm{ha}$ during both seasons, and the highest plant height was under $300 \mathrm{kgN}$ / ha with average of $143.23 \mathrm{~cm}$ in the first season and $165.45 \mathrm{~cm}$ in the second season.

Leaf area index (LAI):

There is no significant differences in LAI due to $\mathrm{N}$ rates fertilization, and LAI ranged between $4.65-4.17 \mathrm{~cm} 2$ during first season, and 3.20-3.02 $\mathrm{cm} 2$ during the second season.

TABLE (3): MEANS OF FLOWERING DATE (DAY), PLANT HEIGHT (CM) AND LEAF AREA INDEX (LAI) OF SUNFLOWER UNDER THE EFFECT OF NITROGEN FERTILIZER RATES, DURING 2016/2017, AND 2017/2018 SEASONS.

\begin{tabular}{|c|c|c|c|c|c|c|}
\hline \multirow{2}{*}{$\begin{array}{l}\text { Nitrogen fertilizer rate } \\
\text { (kgN/ha) }\end{array}$} & \multicolumn{2}{|r|}{$\begin{array}{r}\text { Flowering date } \\
\text { (day) }\end{array}$} & \multicolumn{2}{|l|}{$\begin{array}{l}\text { Plant height } \\
\text { (cm) }\end{array}$} & \multicolumn{2}{|l|}{ LAI } \\
\hline & $2016 / 17$ & $2017 / 18$ & $2016 / 17$ & $2017 / 18$ & $2016 / 17$ & $2017 / 18$ \\
\hline 100 & $.38 \mathrm{~b} 63$ & $57.47 \mathrm{a}$ & $129.46 \mathrm{c}$ & $154.82 \mathrm{c}$ & $4.17 \mathrm{a}$ & $3.02 \mathrm{a}$ \\
\hline 200 & $63.30 \mathrm{~b}$ & a57.22 & $135.51 \mathrm{~b}$ & $157.05 \mathrm{~b}$ & $4.65 \mathrm{a}$ & $3.04 \mathrm{a}$ \\
\hline 300 & $64.36 \mathrm{a}$ & a57.44 & $143.23 \mathrm{a}$ & $165.45 \mathrm{a}$ & $4.48 \mathrm{a}$ & $3.20 \mathrm{a}$ \\
\hline RLSD (0.05) & 0.61 & 0.37 & 2.90 & 1.84 & 0.65 & 0.22 \\
\hline
\end{tabular}

*: Means followed by the same letter are not significantly different according to RLSD at $\mathrm{P} \leq 0.05$.

Effects of defoliation rates on Sunflower growth parameters Flowering date:

There were no significant differences in the flowering dates under the effect of the three defoliation rates in the two seasons. The date of flowering in the first season ranged from 63.77 days to 63.63 days, while in the second season from (57.63 days to 57.16 days) (table 4 ).

Plant height $(\mathrm{cm})$ :

The results (table 4) showed a significant increase in the height of the plant with an increase in the number of leaves removed from the plant in the two seasons. The longest plants were under 4 leaves removal from the plant with an average of $138.13 \mathrm{~cm}$ in the first season, $161.55 \mathrm{~cm}$ in the second season.

Leaf area index (LAI) (cm2):

There were no significant differences in LAI under the influence of the three defoliation rates in the two seasons. LAI ranged between $4.62-4.23$ in the first season and 2.98 3.20 in the second season (table 4).

TABLE (4). MEANS OF FLOWERING DATE (DAY), PLANT HEIGHT (CM) AND LEAF AREA INDEX (LAI) OF SUNFLOWER UNDER THE EFFECT OF DEFOLIATION TREATMENTS, DURING 2016/2017 AND 2017/2018 SEASONS.

\begin{tabular}{|c|c|c|c|c|c|c|}
\hline \multirow{2}{*}{$\begin{array}{c}\text { Defoliation } \\
\text { treatments }\end{array}$} & \multicolumn{2}{|c|}{$\begin{array}{c}\text { Flowering date } \\
\text { (day) }\end{array}$} & \multicolumn{2}{c|}{$\begin{array}{c}\text { Plant height } \\
\text { (cm) }\end{array}$} & \multicolumn{2}{c|}{ LAI } \\
\cline { 2 - 7 } & $2016 / 17$ & $2017 / 18$ & $2016 / 17$ & $2017 / 18$ & $2016 / 17$ & $2017 / 18$ \\
\hline Without defoliation & $63.63 \mathrm{a}$ & $57.63 \mathrm{a}$ & $133.92 \mathrm{c}$ & $155.88 \mathrm{c}$ & $4.44 \mathrm{a}$ & $2.99 \mathrm{a}$ \\
\hline 2 leaves removed & $63.77 \mathrm{a}$ & 57.33 & $136.16 \mathrm{~b}$ & $159.89 \mathrm{~b}$ & $4.23 \mathrm{a}$ & $2.98 \mathrm{a}$ \\
\hline 4 leaves removed & $63.63 \mathrm{a}$ & $57.16 \mathrm{a}$ & $138.13 \mathrm{a}$ & $161.55 \mathrm{a}$ & $4.62 \mathrm{a}$ & $3.20 \mathrm{a}$ \\
\hline RLSD (0.05) & 0.45 & 0.52 & 1.46 & 1.43 & 0.39 & 0.36 \\
\hline
\end{tabular}

*: Means followed by the same letter are not significantly different according to RLSD at $\mathrm{P} \leq 0.05$.

Effects of sunflower cultivars on plants growth parameters Flowering date:

Sunflower cultivars varied in flowering date in the two seasons. The cultivar Sakha 53 was the one with the longest flowering date in the first season (66.97 days), and in the second season the cultivar with the longest flowering date was Hybrid May with 58.02 days (table 5).

Plant height $(\mathrm{cm})$ :

The results showed that Sakha 53 has significantly the highest plant height than the other two varieties reaching $(161.80 \mathrm{~cm})$ in the first season, and $(163.96 \mathrm{~cm})$ in the second season, followed by the Argentinian variety. The most significantly short cultivar was the Turkish variety with $(115.49 \mathrm{~cm}, 136.61 \mathrm{~cm})$ plant height in the first and second seasons respectively (table 5$)$.

Leaf area index (LAI) (cm2):

The highest values of the LAI were of the cultivar Argentinian $(4.65 \mathrm{~cm} 2)$ in the first season and $(3.32 \mathrm{~cm} 2)$ in the second season. Followed by the Egyptian Sakha 53 and the lowest LAI values were those of the Turkish cultivar (Hybrid May) giving $(4.30 \mathrm{~cm} 2)$ in the first season, and $(2.78$ $\mathrm{cm} 2$ ) in the second season (table 5). 
TABLE (5) : MEANS OF FLOWERING DATE (DAY), PLANT HEIGHT (CM) AND LEAF AREA INDEX (LAI) OF SUNFLOWER UNDER CULTIVARS TREATMENTS, DURING 2016/2017 AND 2017/2018 SEASONS.

\begin{tabular}{|l|c|c|c|c|c|c|}
\hline \multirow{2}{*}{ Cultivars } & \multicolumn{2}{|c|}{$\begin{array}{c}\text { Flowering date } \\
\text { (day) }\end{array}$} & \multicolumn{2}{c|}{$\begin{array}{c}\text { Plant height } \\
\text { (cm) }\end{array}$} & \multicolumn{2}{c|}{ LAI } \\
\cline { 2 - 7 } & $2016 / 17$ & $2017 / 18$ & $2016 / 17$ & $2017 / 18$ & $2016 / 17$ & $2017 / 18$ \\
\hline Sakha 53 & $66.97 \mathrm{a}$ & $57.05 \mathrm{~b}$ & $161.80 \mathrm{a}$ & $163.96 \mathrm{a}$ & $4.35 \mathrm{~b}$ & $3.18 \mathrm{ab}$ \\
\hline Argentina 11 & $63.80 \mathrm{~b}$ & $57.05 \mathrm{~b}$ & $130.91 \mathrm{~b}$ & $146.76 \mathrm{~b}$ & $4.65 \mathrm{a}$ & $\mathrm{a} 3.32$ \\
\hline Hybrid May & $60.27 \mathrm{c}$ & $58.02 \mathrm{a}$ & $115.49 \mathrm{c}$ & $136.61 \mathrm{c}$ & $4.30 \mathrm{~b}$ & $2.77 \mathrm{c}$ \\
\hline RLSD (0.05) & 0.49 & 0.55 & 1.14 & 1.28 & 0.29 & 0.49 \\
\hline
\end{tabular}

*: Means followed by the same letter are not significantly different according to RLSD at $\mathrm{P} \leq 0.05$.

Effects of interaction between nitrogen rates and sunflower cultivars on plants agronomic traits

Plant height

Plant height was significantly affected by interaction effect of nitrogen and cultivars in the two seasons. The longest plants during the first season were the Egyptian Sakhra 53 fertilized with a rate of $300 \mathrm{~kg} \mathrm{~N} /$ ha giving $167.73 \mathrm{~cm}$, and the longest plants during the second season was Hybrid May giving $174.18 \mathrm{~cm}$ also under $300 \mathrm{~kg} \mathrm{~N} / \mathrm{ha}$ (table 6).

TABLE (6). MEANS OF PLANT HEIGHT (CM) OF SUNFLOWER UNDER INTERACTION BETWEEN NITROGEN FERTILIZER RATE AND CULTIVARS DURING 2016/2017 AND 2017/2018 SEASONS.

\begin{tabular}{|c|c|c|c|c|c|c|}
\hline \multirow{3}{*}{$\begin{array}{l}\mathrm{N} \\
\mathrm{kgN} / \mathrm{ha}\end{array}$} & \multicolumn{6}{|c|}{ Plant height $(\mathrm{cm})$} \\
\hline & \multicolumn{2}{|l|}{ Sakha 53} & \multicolumn{2}{|l|}{ Argentina } & \multicolumn{2}{|l|}{ Hybrid May } \\
\hline & Season 1 & Season 2 & Season 1 & Season 2 & Season 1 & Season 2 \\
\hline 100 & 154.36 & 159.40 & 125.28 & 142.03 & 108.75 & 163.05 \\
\hline 200 & 163.31 & 162.70 & 128.95 & 145.86 & 114.28 & 162.60 \\
\hline 300 & 167.73 & 169.78 & 138.52 & 152.38 & 123.45 & 174.18 \\
\hline LSD & 1.98 & 2.23 & 1.98 & 2.23 & 1.98 & 2.23 \\
\hline
\end{tabular}

Seed quality

In Table (7) the effect of nitrogen fertilization rates was significant at level of 0.01 on both the content of the oil in the second season and on protein content in the two seasons and on chlorophyll content in the first season. The effect of defoliation factors and cultivars was also significant at $(\mathrm{P} \leq$
0.01 ) on the three traits during both seasons. The effect of the interaction between the nitrogen and cultivars was significant on all three traits in the two seasons, and the effect of the interaction between defoliation and the cultivars on the oil content and the chlorophyll content was also significant during both seasons.

TABLE (7) ANALYSIS OF VARIANCE OF VARIANCE OF OIL CONTENT SEED, PROTEIN CONTENT AND TOTAL CHLOROPHYLL CONTENT OF THE LEAVES OF SUNFLOWER UNDER THE EFFECTS OF NITROGEN FERTILIZER RATES, DEFOLIATION AND CULTIVARS AND THEIR INTERACTIONS DURING 2016/2017 AND 2107/2018 SEASONS.

\begin{tabular}{|c|c|c|c|c|c|c|c|}
\hline \multirow{2}{*}{ Source of variation } & \multirow{2}{*}{ df } & \multicolumn{2}{|c|}{ Oil content } & \multicolumn{2}{|c|}{ Protein content } & \multicolumn{2}{|c|}{ Total chlorophyll content } \\
\hline & & $2016 / 17$ & $2017 / 18$ & $2016 / 17$ & $2017 / 18$ & $2016 / 17$ & $2017 / 18$ \\
\hline Replicates & 3 & $0.04 \mathrm{NS}$ & $0.03 \mathrm{NS}$ & $2987.24 \mathrm{NS}$ & $0.04 \mathrm{NS}$ & $0.03 \mathrm{NS}$ & $0.02 \mathrm{NS}$ \\
\hline Nitrogen fertilizer rates $(N)$ & 2 & $29.32 \mathrm{NS}$ & $29.64 * *$ & $38.75 * *$ & $92.56 * *$ & $1.39 * *$ & $0.88 \mathrm{NS}$ \\
\hline Error (a) & 6 & 0.20 & 0.12 & 3.18 & 0.01 & 0.01 & 0.01 \\
\hline Defoliation (D) & 2 & $3.95 * *$ & $3.68 * *$ & $3.00 * *$ & $1.34 * *$ & $0.07 * *$ & $0.59 * *$ \\
\hline $\mathbf{N * D}$ & 4 & $0.35 \mathrm{NS}$ & $0.30 \mathrm{NS}$ & $0.17 \mathrm{NS}$ & $0.09 \mathrm{NS}$ & $0.01 \mathrm{NS}$ & $0.11 * *$ \\
\hline Error (b) & 18 & 0.22 & 0.10 & 0.16 & 0.02 & 0.01 & 0.01 \\
\hline Cultivars (V) & 2 & $89.99 * *$ & $99.37 * *$ & $192.59 * *$ & $366.81 * *$ & $0.57 * *$ & $0.47 * *$ \\
\hline $\mathbf{N} * \mathbf{V}$ & 4 & $4.51 * *$ & $6.92 * *$ & $7.52 * *$ & $14.92 * *$ & $0.10 * *$ & $0.03 * *$ \\
\hline $\mathbf{D} * \mathbf{V}$ & 4 & $0.49 * *$ & $1.60 * *$ & $0.15 \mathrm{NS}$ & $0.02 \mathrm{NS}$ & $0.02 * *$ & $0.03 * *$ \\
\hline $\mathbf{N} * \mathbf{D} * \mathbf{V}$ & 8 & $0.19 \mathrm{NS}$ & $0.15 \mathrm{NS}$ & $0.17 \mathrm{NS}$ & $0.01 \mathrm{NS}$ & $0.001 \mathrm{NS}$ & NS 0.002 \\
\hline Error $(c)$ & 54 & 0.12 & 0.10 & 0.12 & 0.01 & 0.001 & 0.001 \\
\hline
\end{tabular}

NS: Not significant at $\mathrm{P} \leq 0.05 *$ : significant at $\mathrm{P} \leq 0.0 * *$ : significant at $\mathrm{P} \leq 0.01$

Effects of Nitrogen fertilizer rates on Sunflower seed quality

Seed oil content:

The results for oil seed content showed that there was no significant difference between 100 and $200 \mathrm{~kg} \mathrm{~N} /$ ha on the oil content during both seasons while the lowest values were the result of the effect of $300 \mathrm{~kg} \mathrm{~N} /$ ha with $39.01 \%$ in the first season, $39.63 \%$ the second season.

Protein content: 
Seed protein content increased significantly with increase in $\mathrm{N}$ fertilization from 100 to $300 \mathrm{kgN} /$ ha reaching percentages of $25.11 \%$ during first season and $21.76 \%$ during second season (table 8).

- Chlorophyll content:
Leaves content of chlorophyll significantly increased with increase in $\mathrm{N}$ up to $300 \mathrm{kgN} / \mathrm{ha}$ during first season, and during second season the highest content of chlorophyll was under $200 \mathrm{kgN} / \mathrm{ha}$ (table 8).

TABLE (8) MEANS OF OIL CONTENT (\%), SEED PROTEIN CONTENT (\%) AND TOTAL CHLOROPHYLL OF LEAVES (MG/G) OF SUNFLOWER UNDER THE EFFECTS OF NITROGEN FERTILIZER RATES, DURING 2016/2017, AND 2017/2018 SEASONS.

\begin{tabular}{|c|c|c|c|c|c|c|}
\hline \multirow{2}{*}{$\begin{array}{l}\text { Nitrogen fertilizer rate } \\
\text { (kgN/ha) }\end{array}$} & \multicolumn{2}{|c|}{$\begin{array}{c}\text { Oil content } \\
(\%)\end{array}$} & \multicolumn{2}{|c|}{$\begin{array}{c}\text { Protein content } \\
(\%)\end{array}$} & \multicolumn{2}{|c|}{$\begin{array}{c}\text { Total chlorophyll } \\
(\mathrm{mg} / \mathrm{g})\end{array}$} \\
\hline & $2016 / 17$ & $2017 / 18$ & $2016 / 17$ & $2017 / 18$ & $2016 / 17$ & $2017 / 18$ \\
\hline 100 & $40.47 \mathrm{a}^{*}$ & $41.22 \mathrm{a}$ & $23.10 \mathrm{~b}$ & $18.57 \mathrm{c}$ & $2.63 \mathrm{c}$ & $2.74 \mathrm{c}$ \\
\hline 200 & $40.66 \mathrm{a}$ & $41.18 \mathrm{a}$ & $24.53 \mathrm{a}$ & $20.40 \mathrm{~b}$ & $2.79 \mathrm{~b}$ & $3.05 \mathrm{a}$ \\
\hline 300 & $39.01 \mathrm{~b}$ & $39.63 \mathrm{~b}$ & $25.11 \mathrm{a}$ & $21.76 \mathrm{a}$ & $3.02 \mathrm{a}$ & $2.97 \quad b$ \\
\hline RLSD (0.05) & 0.26 & 0.20 & 1.03 & 0.05 & 0.03 & 0.05 \\
\hline
\end{tabular}

*: Means followed by the same letter are not significantly different according to RLSD at $\mathrm{P} \leq 0.05$.

\section{Effects of defoliation rates on Sunflower seed quality}

Seed oil content:

The highest seed oil content was obtained from removal of 4 leaves and the least oil content was from the treatment without leaves removal, and seed oil content ranged between $40.42 \%$ and $39.78 \%$ in the first season and 40.91 and $40.31 \%$ in the second season (table 9).

Seed protein content:

Also the highest seed protein content was under 4 leaves removal treatment, then the 2 leaves removal and the one with least value is without leaves removal, and the highest seed protein content was $24.52 \%$ during first season and $20.33 \%$ during second season.

Chlorophyll content

The highest leaf chlorophyll content was under 4 leaves removal treatment $(3.05 \mathrm{mg} / \mathrm{g})$, followed by the 2 leaves removal $(2.91 \mathrm{mg} / \mathrm{g})$ and the one with least value is without leaves removal $(2.80 \mathrm{mg} / \mathrm{g})$, during second season.

TABLE (9) MEANS OF OIL CONTENT (\%), SEED PROTEIN CONTENT (\%) AND TOTAL CHLOROPHYLL OF LEAVES (MG/G) OF SUNFLOWER UNDER THE EFFECT OF DEFOLIATION TREATMENTS, DURING 2016/2017 AND 2017/2018 SEASONS.

\begin{tabular}{|l|l|l|l|l|c|c|}
\hline \multirow{2}{*}{$\begin{array}{l}\text { Defoliation } \\
\text { treatments }\end{array}$} & \multicolumn{2}{|c|}{$\begin{array}{c}\text { Oil content } \\
(\%)\end{array}$} & \multicolumn{2}{c|}{$\begin{array}{c}\text { Protein content } \\
(\%)\end{array}$} & \multicolumn{2}{c|}{$\begin{array}{c}\text { Total chlorophyll } \\
\text { (mg/g) }\end{array}$} \\
\cline { 2 - 7 } & $2016 / 17$ & $2017 / 18$ & $2016 / 17$ & $2017 / 18$ & $2016 / 17$ & $2017 / 18$ \\
\hline Without defoliation & $39.78 \mathrm{~b}$ & $40.31 \mathrm{~b}$ & $23.95 \mathrm{c}$ & $20.02 \mathrm{~b}$ & $2.77 \mathrm{~b}$ & $2.80 \mathrm{c}$ \\
\hline 2 leaves removed & $39.94 \mathrm{~b}$ & $40.81 \mathrm{a}$ & $24.27 \mathrm{~b}$ & $20.37 \mathrm{a}$ & $2.82 \mathrm{a}$ & $2.91 \mathrm{~b}$ \\
\hline 4 leaves removed & $40.42 \mathrm{a}$ & $40.91 \mathrm{a}$ & $24.52 \mathrm{a}$ & $20.33 \mathrm{a}$ & $2.85 \mathrm{a}$ & $3.05 \mathrm{a}$ \\
\hline RLSD (0.05) & 0.23 & 0.16 & 0.20 & 0.07 & 0.03 & 0.02 \\
\hline
\end{tabular}

*: Means followed by the same letter are not significantly different according to RLSD at $\mathrm{P} \leq 0.05$.

Effects of sunflower cultivars on seed quality

Seed oil content:

Cultivars varied significantly in oil content in seeds, with the Egyptian cultivar Sakha 53 giving the highest oil content percentage $(41.82-42.50 \%)$ in the two seasons respectively, seconded by the Turkish (Hybrid May) and the cultivar with the least oil content was Argentina with (38.78-39.24 \%) during first and second seasons respectively (table 10).

Seed protein content:
The cultivar with the highest seed protein content was the Turkish (Hybrid May) with 26.92 and $23.88 \mathrm{mg} / \mathrm{g}$ during the two seasons respectively, seconded by Argentina and the Egyptian cultivar gave the least seed protein content during both seasons (table 10).

Chlorophyll content:

No significant differences between the two cultivars Sakha 53 and Argentina in leaf chlorophyll content and they gave $2.90-2.88 \mathrm{mg} / \mathrm{g}$ respectively dominating cultivar Hybrid May during first season (table 10).

TABLE (10) MEANS OF OIL CONTENT (\%), SEED PROTEIN CONTENT (\%) AND TOTAL CHLOROPHYLL OF LEAVES (MG/G) OF THE STUDIED SUNFLOWER CULTIVARS DURING 2016/2017 AND 2017/2018 SEASONS.

\begin{tabular}{|c|c|c|c|c|c|c|}
\hline \multirow[t]{2}{*}{ Cultivars } & \multicolumn{2}{|c|}{$\begin{array}{l}\text { Oil content } \\
(\%)\end{array}$} & \multicolumn{2}{|c|}{$\begin{array}{c}\text { Protein content } \\
(\%)\end{array}$} & \multicolumn{2}{|c|}{$\begin{array}{c}\text { Total chlorophyll } \\
(\mathrm{mg} / \mathrm{g})\end{array}$} \\
\hline & $2016 / 17$ & $2017 / 18$ & $2016 / 17$ & $2017 / 18$ & $2016 / 17$ & $2017 / 18$ \\
\hline Sakha 53 & $41.82 \mathrm{a}$ & $42.50 \mathrm{a}$ & $22.89 \mathrm{~b}$ & $17.91 \mathrm{c}$ & $2.90 \mathrm{a}$ & $2.91 \mathrm{~b}$ \\
\hline Argentina 11 & $38.78 \mathrm{c}$ & $39.24 \mathrm{c}$ & $22.93 b$ & $18.93 \mathrm{~b}$ & $2.88 \mathrm{a}$ & $3.03 \mathrm{a}$ \\
\hline Hybrid May & $39.55 b$ & $40.30 \mathrm{~b}$ & $26.92 a$ & $23.88 \mathrm{a}$ & $2.67 \mathrm{~b}$ & $2.81 \mathrm{c}$ \\
\hline RLSD (0.05) & 0.16 & 0.19 & 1.03 & 0.05 & 0.04 & 0.02 \\
\hline
\end{tabular}

*: Means followed by the same letter are not significantly different according to RLSD at $\mathrm{P} \leq 0.05$. 
Effects of interaction between Nitrogen fertilizer rates and cultivars on seed quality

Seed oil content:

There were significant differences between interaction treatments and the highest seed oil content was $42.62 \%$ by Sakha 53 under $\mathrm{N}$ fertilization of $100 \mathrm{kgN} / \mathrm{ha}$ during the first season and $43.58 \%$ during the second season. The lowest seed oil content was given by Argentina cultivar (37.96 $38.50 \%$ ) under $300 \mathrm{kgN} / \mathrm{ha}$ during the two seasons respectively (table 11).

\section{Seed protein content:}

Table (11) shows that the highest seed protein content was given by the Turkish cultivar (Hybrid May)fertilized by 300
$\mathrm{kgN} / \mathrm{ha}(26.99-23.88 \%)$ during the two seasons respectively, and the lowest protein content was gien by Sakha 53 $(16.67 \%)$ during second season.

Leaf chlorophyll content:

The highest leaf chlorophyll content was given by the two cultivars Sakha 53 under $300 \mathrm{kgN} / \mathrm{ha}$ fertilization during the first season $(3.21 \mathrm{mg} / \mathrm{g})$, and also by cultivar Argentina under $200 \mathrm{kgN} / \mathrm{ha}$ during second season $(3.19 \mathrm{mg} / \mathrm{g})$. The least chlorophyll content was given by cultivar Hybrid May under $100 \mathrm{kgN} / \mathrm{ha}$ during the two seasons $(2.53-2.67 \mathrm{mg} / \mathrm{g}$ ) (table 11).

TABLE (11). MEANS OF OIL CONTENT SEED (\%), SEED PROTEIN CONTENT (\%) AND TOTAL CHLOROPHYLL OF LEAVES (MG/G) OF SUNFLOWER UNDER THE INTERACTION BETWEEN NITROGEN FERTILIZER RATE AND CULTIVARS DURING 2016/2017 AND 2017/2018 SEASONS

\begin{tabular}{|c|c|c|c|c|c|c|c|}
\hline \multirow{2}{*}{$\begin{array}{l}\text { Nitrogen fertilizer rate } \\
\text { (kgN/ha) }\end{array}$} & \multirow[t]{2}{*}{ Cultivar } & \multicolumn{2}{|c|}{$\begin{array}{l}\text { Oil content } \\
(\%)\end{array}$} & \multicolumn{2}{|c|}{$\begin{array}{l}\text { Protein content } \\
(\%)\end{array}$} & \multicolumn{2}{|c|}{$\begin{array}{l}\text { Total chlorophyll } \\
(\mathrm{mg} / \mathrm{g})\end{array}$} \\
\hline & & $2016 / 17$ & $2017 / 18$ & 2016/17 & $2017 / 18$ & $2016 / 17$ & $2017 / 18$ \\
\hline \multirow{3}{*}{100} & Sakha 53 & 42.62 & 43.58 & 22.29 & 16.67 & 2.65 & 2.75 \\
\hline & Argentina 11 & 38.45 & 38.85 & 22.01 & 18.01 & 2.71 & 2.81 \\
\hline & Hybrid May & 40.36 & 41.23 & 24.99 & 21.02 & 2.53 & 2.67 \\
\hline \multirow{3}{*}{200} & Sakha 53 & 42.34 & 42.91 & 23.19 & 18.10 & 2.82 & 3.00 \\
\hline & Argentina 11 & 39.93 & 40.37 & 23.41 & 19.21 & 2.84 & 3.19 \\
\hline & Hybrid May & 39.70 & 40.27 & 26.99 & 23.88 & 2.71 & 2.94 \\
\hline \multirow{3}{*}{300} & Sakha 53 & 40.49 & 41.00 & 23.18 & 18.96 & 3.21 & 2.99 \\
\hline & Argentina 11 & 37.96 & 38.50 & 23.38 & 19.59 & 3.08 & 3.10 \\
\hline & Hybrid May & 38.58 & 39.39 & 28.77 & 26.74 & 2.71 & 2.81 \\
\hline RLSD (0.05) & & 0.28 & 0.32 & 0.28 & 0.06 & 0.07 & 0.03 \\
\hline
\end{tabular}

NS: Not significant at $\mathrm{P} \leq 0.05$

\section{DISCUSSION}

The results obtained showed the significant effects of nitrogen fertilization, defoliation and cultivars on growth and growth components and seed quality of sunflower. Application of nitrogen fertilizer affected sunflower flowering date, where it became longer with increase in $\mathrm{N}$ rates up to $300 \mathrm{kgN} / \mathrm{ha}$. Increase in N rates up to $300 \mathrm{kgN} / \mathrm{ha}$ increased plant height. Application of $\mathrm{N}$ rates also affected leaf area index (LAI) with no significant differences between $\mathrm{N}$ rates. Nitrogen fertilizer is essentially the important natural element needed by the plants for healthy, hastened and convenient growth. Once added to the soil, it fulfills the required demands of the plants, and works in a hastened manner on the plants in the required time-frame. Haque and Jakhro (2001) indicated that the high concentration of nitrogen, leads to an increase in the number of cells and the cell size of the leaf with an overall increase in leaf production, and this may be explained by the fact that nitrogen is a necessary component of amino acids, which are the building blocks of proteins and nucleic acids, which prepare genetic material and protein which are useful in plant growth and also encourage a fast growth. The results obtained in this study agree with many results obtained by researchers. Frazen (2016) explained that sunflower plants efficiency for exploitation of nitrogen is relatively high, and the addition of nitrogen increases plant height. Salih (2013) documented significant increase in height of sunflower plant, the dry weight of the plant and the seed production, with increase in the nitrogen fertilization rate from zero to $184 \mathrm{~kg} \mathrm{~N} / \mathrm{ha}$. Mina Kiani et al. (2016) in Iran tested effect of three levels of nitrogen fertilizer on sunflower and obtained significant increase in the total biomass production. Nitrogen application significantly affected sunflower seed quality, seed oil content of sunflower cultivars was decreased with increase in $\mathrm{N}$ rates, and the lowest seed oil content was attained with application of $300 \mathrm{kgN} / \mathrm{ha}$. Seed protein content increased with increase in $\mathrm{N}$ fertilization up to $300 \mathrm{kgN} / \mathrm{ha}$. Also leaf chlorophyll content increased with increase in $\mathrm{N}$ rate up to $300 \mathrm{kgN} / \mathrm{ha}$. Defoliation affected sunflower growth and growth components. Sunflower plant height was affected by defoliation and the highest plant height was attained with 4 leaves removal, but defoliation didn't affect flowering date and LAI. Many researchers worked on effects of leaves removal on agronomic characters of sunflower. It seems that sunflower can compensate the loss of the leaves removed in the defoliation process through increase in leaf area of the remaining leaves or by development of new leaves. This is supported by Severinoa et al. (2010) who removed leaves from castor oil plant (Ricinus communis) at rate of $0,15,30$, 45 or $60 \%$ of the total leaf area to assess the effect of leaf fall on growth and production components, the total area of 
leaves were reduced but plants were able to fully regrow the leaf area. Also Moriondoa et al. (2003) removed 50\% of the sunflower leaf area in different plant growth stages, and found that removal of leaves during vegetative stage initiated significant increase in the leaf area, which compensated for the decrease in light intercept during the season, while subsequent treatments, during flowering and full flower maturity, showed no increase in single leaf area. AL-Dori and Hassan (2011) treated 3 sunflowers cultivars with three levels (without removing leaves, removing 4 leaves and removing 8 leaves) and found that the highest values for plant height, stem diameter, leaf area, were for the treatment without leaf removal. On the other hand response of sunflower cultivars varied significantly with $\mathrm{N}$ and defoliation treatments. The results obtained in this study revealed significant differences between the sunflower cultivars ( the Egyptian variety Sakha 53, Argentina cultivar and the Turkish variety Hybrid May) in their responses to $\mathrm{N}$ fertilization and defoliation treatments regarding growth and growth components, yield and yield components, sunflower seed qualities and soil characteristics. Regarding sunflower growth parameters, Sakha 53 and Hybrid May cultivars gave the highest flowering date, and for plant height Sakha 53 dominated giving the highest value, while the cultivar Argentina gave the highest LAI value. For yield and yield components, cultivar Argentina gave the highest seed weight per plant, the highest weight of 100 seeds and the highest seed yield per hectare, while cultivar Sakha 53 dominated in head diameter. For seed quality, Sakha 53 gave the highest seed oil percentage and highest leaf chlorophyll value while Argentina cultivar gave the highest seed protein percentage. Argentina cultivar also dominated giving the highest soil $\mathrm{N}$ percentage.

\section{CONCLUSION}

The results of this research concluded the significant effects of $\mathrm{N}$, defoliation and cultivars and their interactions on sunflower growth and growth parameters, and sunflower seed quality. Application of nitrogen fertilizer up to 300 $\mathrm{kgN} / \mathrm{ha}$ significantly increased sunflower flowering date, seed protein content, leaf chlorophyll. But seed oil content was reduced by increase in $\mathrm{N}$ rates up to $300 \mathrm{kgN} / \mathrm{ha}$. On the other hand increase in $\mathrm{N}$ rates up to $300 \mathrm{kgN} / \mathrm{ha}$ also affected leaf area index (LAI) with no significant differences between $\mathrm{N}$ rates. Removal of leaves (defoliation) significantly affected growth of sunflower cultivars, and the highest plant, the highest values of the percentages of seed oil, seed protein, and leaf chlorophyll content were attained under the defoliation treatment of removal of 4 leaves, but defoliation didn't affect flowering date and LAI. The best interaction treatments that gave the highest flowering date in sunflower was by the Egyptian cultivar Sakha 53 with 100 and 200 $\mathrm{kgN} / \mathrm{ha}$ under 2 leaves removal, and also with $300 \mathrm{kgN} / \mathrm{ha}$ under 4 leaves removal and without leaves removal. The best treatment that gave the highest plant height was by the Turkisk cultivar Hybrid May under $300 \mathrm{kgN} /$ ha with 2 leaves removal. For the highest LAI the best interaction treatments was for SAkha 53 under $200 \mathrm{kgN} / \mathrm{ha}$ without leaves removal.
Regarding seed quality, the best combined treatments that gave the highest seed oil percentage was SAkha 53 under 100 $\mathrm{kgN} / \mathrm{ha}$ with 4 leaves removal (Sakha 53 x $100 \mathrm{kgN} / \mathrm{ha}$ x 4 leaves), and for highest seed protein content was (Hybrid May x $300 \mathrm{kgN} / \mathrm{ha}$ x 4 leaves), and for highest leaf chlorophyll was (Argentina and Sakha 53 x $300 \mathrm{kgN} / \mathrm{ha}$ x 4 leaves).

\section{ACKNOWLEDGMENTS}

The researcher wish to thanks King Abdulaziz City for Science and Technology for their financial support to this work (1-17 -04-009-0002)

\section{REFERENCES}

[1] A.O.A.C. Association of Official agricultural Chemists : Official and Tentative Methods. 2000.

[2] S.A.M. Al-Dori. "Effect of Leaves Defoliation and Plant Density on Growth, Yield and Quality of Some Sunflower Genotypes (Helianthus annuus L., Compositae)". College Of Basic Education Researches Journal, 11(3), 724-751. 2011.

[3] M.S. Arif, M. Riaz, S.M. Shahzad, T. Yasmeen, , M.J. Akhtar, M.A. Riaz... \& A. Buttler. "Associative interplay of plant growth promoting rhizobacteria (Pseudomonas aeruginosa QS40) with nitrogen fertilizers improves sunflower (Helianthus annuus L.) productivity and fertility of Aridisol". Applied soil ecology, 108, 238-247. 2016

[4] C.A. Dordas, C. Sioulas. "Dry matter and nitrogen accumulation, partitioning, and retranslocation insafflower (Carthamus tinctoriusL.) as affected by nitrogen fertilization." Field Crops Research 110: 35-43. 2009.

[5] F.S. El-Nakhlawy. Experimental Design and Analysis in the Scientific Research. Sci. Pub. Center, King Abdulaziz University, Jeddah, Saudi Arabia. 2010.

[6] D. Frazen. "Fertilizing sunflower. NDS U Extension Service, Feb. 2016.

[7] Haque, A.A. Jakhro. "Soil and fertilizer potassium". In A. Rashid Soil Science (p.261-263). Islamabad: National Book Foundation. 2001.

[8] J. M. Blumenthal, , D. D. Baltensperger, K.G. Cassman, S.C. Mason, \& A.D. Pavlista. "Importance and effect of nitrogen on crop quality and health". In Nitrogen in the Environment (Second Edition) (pp. 51-70). 2008.

[9] T. Karadogan, I. Akgun, N. Tindal. "Effect of leaf removal on sunflower yield components and some quality characters". Turkish J. of Field crops, vol.14 NO.2, PP:45-54,2009.

[10] C. Laura, R. Jach-Smitha, D. Jacksona. "Nitrogen conservation decreases with fertilizer addition in two perennial grass cropping systems for bioenergy." Agriculture, Ecosystems and Environment 204, 62-71. 2015 .

[11] M. Mina Kiani, M. B, Mostafazadeh-Fard, M. Mahdi Majidi, K. Karchani, H. Gerrit. "Effect of the interaction of water and nitrogen on sunflower under drip irrigation in an arid region". Agricultural Water Management, vol. 171, pp. 162-172. 2016

[12] M.S. Moriondoa, F.J. Orlandinia, M. Villalobos. "Modelling compensatory effects of defoliation on leaf areagrowth and biomass of sunflower (Helianthus annuusL.)". Europ. J. Agronomy 19 (2003) 161-171. 2003.

[13] M. Pansu, J. Gautheyrou. "Handbook of soil analysis Mineralogical, Organic and Inorganic Methods". Springer. PP 983. 2006.

[14] M.N.T. Salih. "Response of sunflower to phosphorus and nitrogen fertilization under rainfed conditions", Sudan HELIA, 36, NO. 58, PP.101-110, 2013.

[15] L.S. Severino, M.A. Freire, A.M. Lucena, L.S. Vale. "Sequential defoliations influencing the development and yield components of castor plants (Ricinus communis L.)". Industrial crops and products, 32(3), 400-404. 2010. 